\title{
Issues Trustees Face in Natural Resource Damage Assessments, Part I
}

\author{
Allan Kanner ${ }^{1}$ \\ Kanner \& Whiteley, LLC, New Orleans, LA, United States \\ Email: a.kanner@kanner-law.com
}

How to cite this paper: Kanner, A. (2017) Issues Trustees Face in Natural Resource Damage Assessments, Part I. Journal of Environmental Protection, 8, 503-523. https://doi.org/10.4236/jep.2017.84035

Received: March 24, 2017

Accepted: April 27, 2017

Published: April 30, 2017

Copyright $\odot 2017$ by author and Scientific Research Publishing Inc. This work is licensed under the Creative Commons Attribution International License (CC BY 4.0).

http://creativecommons.org/licenses/by/4.0/

\section{(c) (i) Open Access}

\begin{abstract}
The Natural Resource Damage Assessment (NRDA) process evaluates natural resource injuries arising from hazardous waste or oil spills and determines the appropriate remedies. In this article, the first of a two part series, I address the issues that Natural Resource Trustees regularly face during the NRDA process outlined in numerous environmental statutes. Large scale environmental disasters call for sound science, but also discretionary and informed decisionmaking specific to the particulars of the scenario faced by the trustee that will make the public whole. If the environmental statutes are read correctly, a NRDA will enable a trustee to make the best decisions regarding restoration plans and damages owed. However, constant challenges to the trustee's authority by the responsible party during the assessment process are not only inconsistent with the trustee's statutorily delegated authority and the purpose of the environmental statutes themselves, but add considerable delay and cost to the restoration process. This article outlines the NRDA process a trustee typically follows while addressing common misinterpretations of statutory authority that often hinder the ultimate goal of environmental restoration.
\end{abstract}

\section{Keywords}

Environmental, Regulations, Trustee, Assessment, Litigation

\section{Introduction}

Under state and federal laws, polluters are responsible for damages associated with injuries to natural resources ${ }^{2}$ resulting from the release of hazardous sub-

${ }^{1}$ The views expressed herein are those of the author and not the views of any clients.

${ }^{2}$ See generally Comprehensive Environmental Response, Compensation and Liability Act ("CERCLA") 42 U.S.C. $\$ \$ 9601-9675$; Oil Pollution Act of 1990 (“OPA”), 33 U.S.C. $\$ \$ 2701-2761$; Clean Water Act ("CWA"), 33 U.S.C. $\$ \$ 1251-1387$. The notion that the polluter pays to prevent and restore environmental damages has also been adopted in European Union Directive 2004/35/EC (ELD, 4121/04); Treaty on the Functioning of the European Union, Article 191(2) TFEU. The Directive defines "environmental damage" as damage to protected species and natural habitats, water and soil. 
stances or petroleum products, ${ }^{3}$ and the costs associated with assessing the same. ${ }^{4}$ The goal of natural resource damage ("NRD") laws and the natural resource damage assessment ("NRDA") process is to make the public whole for the loss of natural resources due to the release of hazardous substances or oil. ${ }^{5}$ The means generally selected by NRD legislation to achieve this goal has been to create the office of trustee to assess the injury to natural resources caused by a release and determine an appropriate remedy [1].

The President has a duty under the Comprehensive Environmental Response, Compensation and Liability Act (CERCLA) ${ }^{6}$ and the Oil Pollution Act (OPA) ${ }^{7}$ to designate trustees for federal natural resources and delegates the same power to the states. Under CERCLA, the secretaries of the cabinet departments of Agriculture, Defense, Interior, Commerce, and Energy have been designated as trustees for the federal natural resources within their respective areas of management, as specified by the National Contingency Plan (NCP). ${ }^{8}$ At the state level, Natural Resource Trustees are designated by the Governor and are typically the secretaries of the environmental agencies; ${ }^{9}$ however, under OPA the Governor has the authority to delegate responsibility to any entity. ${ }^{10}$ State Trustees are responsible for any natural resources found within the boundaries of the state or that belong to, are managed by, controlled by, or appertaining to the State. ${ }^{11} \mathrm{Fi}$ nally, Tribal Chairmen or other heads of the governing bodies of Indian Tribes act as the Tribal Trustees for natural resources belonging to, managed by, controlled by, or appertaining to the tribe. ${ }^{12}$ By appointing trustees that work within the offices and departments that manage natural resources, the Federal and State governments ensure that the most qualified individuals are responsible for managing the NRDA process. To further bolster the finality and efficiency of Natural Resource Trustee's decisions, Congress provided for a rebuttable pre-

\footnotetext{
${ }^{3}$ Hazardous substances are (1) any elements, compounds, mixtures, solutions, or substances specially designated by the United States Environmental Protection Agency ("EPA") under $\$ 311$ of the CWA (40 C.F.R. $\$ 116.4$ ) or under $\$ 102$ of CERCLA (40 C.F.R. $\$ 302.4$ ); (2) any toxic pollutants listed under $\$ 307$ (a) of the CWA; (3) any hazardous substances regulated under $\$ 311(\mathrm{~b})(2)$ (A) of the CWA; (4) any listed or characteristic Resource Conservation and Recovery Act ("RCRA") hazardous wastes; (5) any hazardous air pollutants listed under $\$ 112$ of the Clean Air Act ("CAA"); or (6) any imminently hazardous chemical substances or mixtures regulated under Sect. 7 of the Toxic Substances Control Act ("TSCA"). EPCRA also establishes emergency reporting requirements for "extremely hazardous substances.” (40 C.F.R. $\$ 355,42$ U.S.C. $\$ \$ 9601(6)$, 9607(a)(4)(C)pp. A). The list of extremely hazardous substances is the same list of substances published in Appendix A of the November 1985 "Chemical Emergency Preparedness Program Interim Guidance." These substances are also CWA and CERCLA "hazardous" substances.

${ }^{4}$ See, e.g., 42 U.S.C. $\$ \$ 9601(6), 9607(\mathrm{a})(4)(\mathrm{C})$.

${ }^{5} 42$ U.S.C.A. $\$ \$ 9607(\mathrm{f})(1)$; see generally Allan Kanner \& Mary E. Ziegler, Understanding and Protecting Natural Resources, 17 Duke Envtl. Law \& Policy Forum 119, 120-123 (2006) (discussing the importance of NRD).

${ }^{6} 42$ U.S.C. $\$ 9605(\mathrm{a})(4) ; \$ 9615$

${ }^{7} 33$ U.S.C. $\$ 2706(\mathrm{~b})$.

${ }^{8} 40$ C.F.R. $\$ 300.600$.

${ }^{9}$ Stating that the designated individual "have ready access to appropriate state officials with environmental protection, emergency response, and natural resource responsibilities.” 40 C.F.R. $\$ 300.605$.

${ }^{10} 33$ U.S.C. $\$ 2706(\mathrm{~b})(3)$.

${ }^{11} 40$ C.F.R. $\$ 300.605$.

${ }^{12} 40$ C.F.R. $\$ 300.610$.
} 
sumption for trustee findings so long as the appropriate regulations were followed. ${ }^{13}$ Such deference and experience provides a trustee with the broadest authority possible that allows for the most comprehensive evaluation and eventual restoration of the resources in his or her charge.

While there are several federal environmental statutes that provide for recovery of natural resource damages, the three principal statutes trustees tend to use are (1) the Comprehensive Environmental Response, Compensation and Liability Act ${ }^{14}$ ("CERCLA"), (2) the Clean Water Act ${ }^{15}$ ("CWA"), and (3) the Oil Pollution $\mathrm{Act}^{16}$ ("OPA"). ${ }^{17}$ Regulations for assessing NRD injuries have been promulgated by the U.S. Department of the Interior ("DOI") and the National Oceanic \& Atmospheric Association ("NOAA"). ${ }^{18}$ Some states have also promulgated regulations. ${ }^{19}$ Even without special legislation, the fiduciary responsibilities of the guardian of natural resources are recognized as robust under the common law [2]. ${ }^{20}$ Given the complex and dynamic nature of the environment $[1]^{21}$, NRDA and the methods and computations designed to assess NRD injuries determine an appropriate remedy do not necessarily produce a single "right" answer. For this reason, someone has to make decisions based on the science, law and policy. A trustee is generally designated to interpret and use best judgement

\footnotetext{
${ }^{13} 42$ U.S.C. $\$ 9607(\mathrm{f})(2)(\mathrm{C}) ; 33$ U.S.C. $\$ 2706(\mathrm{e})(2)$.

${ }^{14} 42$ U.S.C. $\$ \$ 9601-9675$.

${ }^{15} 33$ U.S.C. $\$ \$ 1251-1387$.

${ }^{16} 33$ U.S.C. $\$ \$ 2701$ et seq.

${ }^{17}$ There are also NRD provisions in the National Marine Sanctuaries Act, 16 U.S.C. $\$ \$ 1431$ et seq. ("NMSA"); the Deepwater Port Act, 33 U.S.C. $\$ \$ 1501$ et seq.; and the Park System Resources Protection Act, 16 U.S.C. $\$ 19(j)$.

${ }^{18}$ Current DOI NRD regulations are codified at 43 C.F.R. Part 11. DOI issued its first NRD regulations under CERCLA in 1986. 51 Fed. Reg. 27,674. When Congress shortly thereafter enacted the Superfund Amendments and Reauthorization Act ("SARA"), Pub. L. No. 99-4999, 100 Stat. 1613 (1986), DOI published updated NRD regulations in 1986, 1987 and 1988. 51 Fed. Reg. 27725 (Aug. 1, 1986); 52 Fed. Reg. 9095-96 (Mar. 20, 2987); 53 Fed. Reg. 5171-76 (Feb. 22, 1988). In Ohio v. United States Department of Interior, 880 F.2d 432 (D.C. Cir. 1989) (hereinafter Ohio v. DOI), the D.C. Circuit significantly dismantled the 1988 regulations, and DOI promulgated revised regulations in 1994 and 1996. 59 Fed. Reg. 14281-87 (Mar. 25, 1995); 61 Fed. Reg. 20609-14 (May 7, 1996). The D.C. Circuit substantially upheld the 1994 regulations in Kennecott v. Department of Interior, 88 F.3d 1191 (D.C. Cir. 1996). Following additional amendments in 2000 and 2004, 65 Fed. Reg. 6014 (Feb. 8, 2000); 69 Fed. Reg. 18803 (Apr. 9, 2004), DOI chartered a Federal Advisory Committee to recommend further revisions to the NRD regulations in 2005, largely to better reflect the common practice of non-litigious resolution of NRD claims. The Committee released its Final Report in 2007, and DOI issued revised regulations in 2008 that "emphasized resource restoration over economic damages.” 73 Fed. Reg. 57265-68 (Oct. 2, 2008); 73 Fed. Reg. 65274 (Nov. 3, 2008).

Current NOAA NRD regulations are codified at 15 C.F.R. Part 90. NOAA issued its first NRD regulations under OPA in 1996. 61 Fed. Reg. 500 (Jan. 5, 2006). In General Electric Co. v. Department o1 Commerce, 128 F.3d 767 (D.C. Cir. 1997), the D.C. Circuit vacated the portion of the rule dealing with removal of residual oil from spill sites. NOAA published revised regulations in 2002. 67 Fed. Reg. 61492-93 (Oct. 1, 2002).

${ }^{19}$ See, e.g., Washington Admin. Code, W.A.C. 173-183 ("Oil Spill Natural Resource Damage Assessment").

${ }^{20}$ See, Borough of Neptune City v. Borough of Avon-by-the-Sea, 294 A.2d 47, 54 (N.J. 1972). For example, the NRD claim asserted by the state of New Jersey for the Lower Passaic River was brought under the New Jersey Spill Compensation and Control Act, N.J.S.A. 58:10-23.11 et seq.

${ }^{21}$ Sources of complexity in NRDAs are unavoidable data gaps due to the dynamic nature of natural resources, including marshes, beaches, "land, fish, wildlife, biota, air, water, groundwater, drinking water supplies and other such resources...,” 43 C.F.R. $\$ 11.14(\mathrm{z})$, among other issues.
} 
to identify injuries and select commensurate restoration remedies. ${ }^{22}$ As a fiduciary, the trustee must exercise his or her broad discretion to act under all of these circumstances and uncertainties to preserve and enhance natural resources for the benefit of the public. Though there are a number of options available to the trustee to fulfill this duty, the preferred avenue that will best benefit the public and the environment generally involves ecological restoration.

It is important to restore natural resources for many reasons. Whether one's perspective is anthrocentric or ecocentric, restoration increases the quantum of natural resources and associated services that form the basis of social wealth and welfare, as well as ecological productivity. As the court in Ohio V. U.S. Department of Interior noted, environmental laws are to be enforced with a bias for restoration because natural resources are neither fungible goods nor readily quantifiable ones. ${ }^{23}$ In effect, trustees are to restore resources where they are able because attempting to pay damages by quantifying the dollar value of the losses associated with a natural resource injury is a virtual impossibility or likely to underestimate the value of the losses.

Natural resource damage assessments are not the same as site remediation activities, though the two activities may occur sequentially or concurrently. Site remediation is a form of risk management. If the polluter, also referred to as the responsible party ("RP"), can show that it has acted reasonably to lower the risk of future injury to human health and the environment to what regulators consider an acceptable level, the remedial "cleanup" is often deemed complete. Such "cleanups" often include the installation of "engineering controls" like barbed wire fencing, no-access signs, and putting caps on top of the pollution (which usually consists of two feet of relatively clean dirt). In common understanding, and under applicable regulations, site remediation has a very different purpose and endpoint than actually cleaning up or restoring the site to anything resembling its pre-pollution condition. ${ }^{24}$

Protecting and restoring natural resource is different from managing future risks arising from current pollution [3]. "Cleanups" in the context of site remediation are prospective; they are not designed to correct past injuries to the environment or to restore resources to pre-incident or pre-injury baseline condition. A NRDA, in large part, looks back in time to understand the resources prior to ${ }^{22}$ See, e.g., Ohio v. DOI, 880 F.2d at 456.

${ }^{23} 880$ F. $2 \mathrm{~d}$ at 456 . Numerous other reasons exist, including the trustee's singular focus on the trust, as opposed to the typical trade-offs of political life.

${ }^{24}$ See N.J. Dep't of Envtl. Prot. v. Exxon Mobil Corp., 393 N.J. Super. 388, 406 (App. Div. 2007) (“As noted earlier, 'remediation' to risk-based standards is different from "restoration" of natural resources to pre-discharge conditions (primary restoration) or 'replacement' of the ecological services and values lost through compensation (compensatory restoration). Remediation, then, is just one of the processes covered by the broad definition of 'cleanup and removal costs', a more restricted and technical term, whose language of limitation first appeared in the Spill Act in 2001 as part of the amendments approved in L. 2001, c.154, and which was actually imported from other legislation with a different focus and purpose."). As Frank Messina, ExxonMobil's Site Remediation Manager for the Bayway site in Linden, New Jersey, acknowledged in the 2014 NRD trial against ExxonMobil, ExxonMobil's remedial investigation efforts have not cleaned up a "speck" of contamination or restored the natural resources of the State. N.J. Dep't of Envtl. Prot. v. ExxonMobil Corp., Nos. UNN-L-302604, UNN-L-4415-04 (N.J. Super. Ct. Law Division), Trial Tr. (Aug. 29, 2014) 15:24 -17:3. 
the injury which dictates the appropriate restoration objective. Despite their different endpoints, site remediation data and histories can be valuable in the NRD process [4]. ${ }^{25}$

The following discussion summarizes some of the issues trustees confront in most NRDAs. ${ }^{26}$ It is important to remember at the outset that every natural ecosystem-and therefore every environmental injury-is unique. Therefore, a trustee's analysis is always site-specific and relies heavily on decisions left to the trustee's discretion [4]. ${ }^{27}$ Rarely can he or she study all injuries at all levels comprehensively. In its Damage Assessment following the Deepwater Horizon Oil Spill, NOAA stated:

The injuries caused by the Deepwater Horizon spill cannot be fully described at the level of a single species, a single habitat type, or a single region. Rather, the injuries affected such a wide array of linked resources over such an enormous area that the effects of the Deepwater Horizon spill must be described as constituting an ecosystem-level injury. Consequently, the Trustees' preferred alternative for a restoration plan employs a comprehensive, integrated ecosystem approach to best address these ecosystem-level injuries. ${ }^{28}$

Priorities must be set and leading indicators selected. "NRDAs can vary significantly in complexity and this variation in complexity affects the application of the scientific steps in the NRDA" [4]. ${ }^{29}$ Notwithstanding these site-specific differences, the following issues are common to most NRDAs.

\section{Restoration Is Paramount}

In NRD matters, the favorite goal is restoration. The D.C. Circuit's decision in Ohio v. DOI clarified that the primary objective of a NRDA is restoration: "Congress established a distinct preference for restoration cost as the measure of recovery in natural resource damage cases." ${ }^{30}$ In reaching this conclusion, the court rejected a rule previously promulgated by the DOI, which specified that "damages for despoilment of natural resources shall be 'the lesser of: restoration or replacement costs; or diminution of use values." ${ }^{31}$ This rule would have re-

\footnotetext{
${ }^{25}$ Funded by industry's "Ad Hoc Industry Natural Resource Management Group, Information and data acquired while determining the extent of contamination and during many other aspects of the cleanup process, are important inputs in an NRDA."

${ }^{26}$ Private parties do not have a NRD cause of action. However, NCR Corp. v. George A. Whiting Paper Co., 768 F.3d 682, 709 (7th Cir. 2014) held that a party responsible for NRD under $\$ 107$ might recover some of those costs through a CERCLA $\$ 113$ contribution action.

${ }^{27}$ "Both the types of chemicals released and the nature of the releases can vary greatly among NRDAs, and the NRDA process for each site needs to address site-specific release scenarios."

${ }^{28}$ Plan for Deepwater Horizon Oil Spill Natural Resource Injury Restoration: Overview, available at http://www.gulfspillrestoration.noaa.gov/sites/default/files/wp-content/uploads/Front-Matter-and-C hapter-1_Introduction-and-Executive-Summary_508.pdf, at 1-6.

${ }^{29}$ For example, cost-benefit analysis may not be appropriate where it would improperly skew results. Citizens to Preserve Overton Park, Inc. v. Volpe, 401 U.S. 402 (1971) (stating that a cost-benefit analysis does not apply, for example where using parks would be cheaper for construction of federal highways because the government already owns land because that may thwart the intent to preserve parkland).

${ }^{30}$ Ohio v. DOI, 880 F.2d 432, 441 (D.C. Cir. 1989).

${ }^{31} \mathrm{Id}$.
} 
lieved responsible parties from having to restore or replace injured natural resources to their pre-incident levels; instead, responsible parties only would have been obligated to pay the difference between the use value provided by the damaged resource pre- and post-pollution, assuming that difference was lower than the cost of restoration.

The D.C. Circuit based its decision on its statutory interpretation of CERCLA: The strongest linguistic evidence of Congress' intent to establish a distinct preference for restoration costs as the measure of damages is contained in $\S$ 107(f)(1) of CERCLA. That section states that natural resource damages recovered by a government trustee are "for use only to restore, replace, or acquire the equivalent of such natural resources." 42 U.S.C.A. $\$ 9607(f)(1)$ (West). It goes on to state: "The measure of damages in any action under [ $\$ 107(\mathrm{a})(\mathrm{c})]$ shall not be limited by the sums which can be used to restore or replace such resources." Id.... By mandating the use of all damages to restore the injured resources, Congress underscored in $\$ 107(\mathrm{f})(1)$ its paramount restorative purpose for imposing damages at all. It would be odd indeed for a Congress so insistent that all damages be spent on restoration to allow a "lesser" measure of damages than the cost of restoration in the majority of cases. ${ }^{32}$

The court thus overturned DOI's requirement that the proper measure of natural resource damages be the "lesser of" restoration costs and the difference in use value provided by the damaged resource pre- and post-pollution.

In addition to establishing the primacy of restoration costs as the proper measure of damages to natural resources, Ohio v. U.S. Department of Interior affirmed that natural resources cannot adequately be valued using a "market fundamentalist" approach that hinges on the commercial value of the damaged resources. ${ }^{33}$ Specifically, the court overturned the DOI's "strong presumption in favor of market price and appraisal methodologies" over other methods of determining compensatory damages. ${ }^{34}$ In the name of "efficiency," DOI had promulgated a hierarchy of assessment methods for determining "use values"-the values provided by sensual contact with natural resources-and seated market values atop it. ${ }^{35}$ That rule stated:

Limited recovery to the price commanded by the resource on the open market, unless the trustee found that "the market for the resource is not reasonably competitive." 43 C.F.R. $\$ 11.83$ (c)(1). If the trustee made such a finding, it could "appraise" the market value in accordance with the relevant sections of the "Uniform Appraisal Standards for Federal Land Acquisition," see 43 C.F.R. $\$$ $11.83(\mathrm{c})(2)$. Only when neither the market value nor the appraisal method was "appropriate" could other methods of determining use value be employed, see 43 C.F.R. $\$ 11.83(\mathrm{~d}){ }^{36}$

The Ohio v. DOI court concluded that DOI's rule reflected an unreasonable

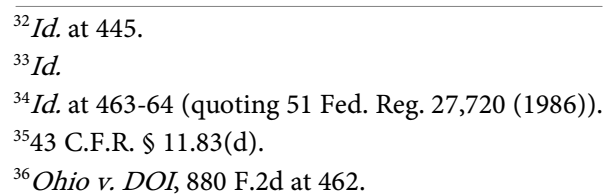


interpretation of CERCLA, because market value cannot capture the full range of utility that people derive from a natural resource. As the court observed, "Congress intended the damage assessment regulations to capture fully all aspects of loss. ${ }^{37}$ The court went on to explain:

CERCLA section 301(c)(2) commands Interior to "identify the best available procedures to determine natural resource damages, including both direct and indirect injury, destruction or loss." 42 U.S.C.A. $\$ 9651$ (c)(2) (West). The Senate CERCLA report stated that assessment procedures should provide trustees " $\mathrm{a}$ choice of acceptable damage assessment methodologies to be employed and should] select the most accurate and credible damage assessment methodologies available." S.Rep. No. 848, 96th Cong., 2d Sess. 85-86 (1980). The current rules defeat this intent by arbitrarily limiting use values to market prices.... While it is not irrational to look to market price as one factor in determining the use value of a resource, it is unreasonable to view market price as the exclusive factor, or even the predominant one. From the bald eagle to the blue whale and snail darter, natural resources have values that are not fully captured by the market system. See Com. of Puerto Rico v. SS Zoe Colocotroni, 628 F.2d 652, 673-74 (1st Cir. 1980), cert. denied, 450 U.S. 912 (1981). DOI's own CERCLA 301 Project Team recognized that "most government resources, particularly resources for which natural resource damages would be sought, may often have no market."38

Congress incorporated Ohio v. DOP s holdings into the Oil Pollution of Act of 1990 (“OPA"), as evidenced by the following excerpt from the bill's Senate Report:

The bill as amended is intended to be consistent with the recent unanimous decisions of the U.S. Court of Appeals for the District of Columbia Circuit in State of Ohio v. Interior..., reversing the Interior Department's narrow market value and use value based approach to assessing damages.... The bill makes it clear that forests are more than board feet of lumber, and that seals and sea otters are more than just commodities traded on the market. ${ }^{39}$

As with CERCLA, then, the value that OPA places on natural resources exceeds whatever value "the market" might place on the same resources, and it expresses a preference for restoration damages over "use value" differential damages. ${ }^{40}$ In order to ascertain the proper restoration damages, trustees must take many steps, face countless challenges, and ultimately use their congressionally approved judgement to make the public whole once more. Yet, just as the law prioritizes restoration, it also prioritizes timeliness and economy of process. ${ }^{41}$

\section{Methodology}

The ultimate outcome of NRDA should generally be restoration of the injured resources. ${ }^{42}$ As noted, NRDAs are rarely amenable to a "one-size-fits-all" me-

${ }^{37}$ Id. at 463-64 (emphasis added).

${ }^{38}$ Id. at $462-64$.

${ }^{39}$ S. Rep. 101-94, 14-15 (1989), reprinted in 1990 U.S.C.C.A.N. 722, 736-797 (emphasis added).

${ }^{40}$ See Natural Resource Damage Assessments, 61 Fed. Reg. 440; General Elec. Co. v. U.S. Dep't or Commerce, 128 F.3d 767, 770-771 (D.C. Cir. 1997),

${ }^{41}$ See 42 U.S.C. $\$ 9604$. 
thodology. Trustees therefore conduct NRDAs on a "site-and-fact-specific basis" [1]. Federal and state laws grant trustees great discretion in developing and managing injury assessments and remedy selections. ${ }^{43}$ With this broad discretion, trustees can complete natural resource restoration by gathering all relevant facts, ${ }^{44}$ and then, with an understanding of restoration goals and priorities, making judgment calls related to any data gaps, the best available science, and applicable law and policy [1].

Trustees have been granted broad discretion because there is rarely a single right answer to the factual, legal, and political questions generated by environmental injuries: When a major oil spill damages intertidal marshes, which portions of the marshes should be restored? To what extent? What methods should be used to effect the restoration? What does restoration mean in a dynamic ecosystem like the Louisiana wetlands?

The few methodological principles that do guide trustees-for example, trustees try to replenish injured ecosystems with the same type and quantity of natural resources that were damaged or destroyed-are difficult to follow due to the complexity of natural ecosystems. Restoration requires a trustee to reestablish an ecosystem's pre-discharge ecological complexity, self-organization, resilience, and sustainability, each of which may have taken millions of years to develop in the first instance.

Due to these complexities, there are situations where traditional restoration of injured resources may not be possible or prudent. When a dynamic marsh erodes in a particular spot, for instance, restoration at that precise spot may not be feasible. In a situation like this, a trustee may prioritize one resource species over another (e.g., by enhancing trout habitat over pike habitat in a steam restoration project), engaging in a habitat or resource equivalency analysis to assess primary and compensatory restoration [1].

NRDAs present trustees with many other difficult questions that impede the systematic adoption of specific methodologies: Which resources should be treated as equivalent? What if it is only possible to restore a less productive resource? What is the anticipated recovery time for the proposed restoration project? How should it be scaled? How much less productive will the restored habitat be compared to the destroyed habitat? When, if at all, will that productivity differential narrow? When is it appropriate to conduct an early restoration project before a formal assessment in order to minimize or prevent additional injury ${ }^{25}$ Difficult questions like these arise in both the assessment of injury and the determination of remedy.

It is important to emphasize that restoration is not an entirely objective, scientific goal. It is a process informed by evolving and disputed ecological val-

${ }^{42}$ See Ohio v. DOI, 880 F.2d 432, 458 (D.C. Cir. 1989) (“The 'primary purpose' of CERCLA's natural resource damages provisions was restoration or replacement of natural resources.").

${ }^{43}$ See, e.g., 15 C.F.R. $\$ 990.27$. OPA and CERLA regulations are explicitly voluntary. 15 C.F.R. $\$ 990.11$; 43 C.F.R. $\$ 11.10$.

${ }^{44}$ C.f. Penn Central Transp. Co. v. New York City, 438 U.S. 104, 124 (1978) (approving ad hoc factual inquiry by court to determine whether a regulatory taking went "too far").

${ }^{45}$ E.g., 15 C.F.R. $\$ 990.26$. 
ues [5] [6] [7], and value-laden terms lacking in scientific objectivity, like "damage" or "restore." ${ }^{\text {"6 }}$ For examples, will all contamination be treated as an injury? Or will the trustee only address certain contaminants?

Trustees must set realistic goals and exercise sound discretion. It is also important that trustees be receptive to relevant information. But even this principle has its limitations, because it is never possible for trustees to gather all information desired. For example, a trustee may want to know the date and exact location of each discharge in assessing damages, but due to the lack of historic record keeping at a facility, or storm conditions during an oil spill, such information may not be possible to obtain. Responsible parties can always hire experts to opine that certain information should have been considered, whether or not such information is possible to obtain. However, such opinions may not always be reasonable. If substantially all natural resources were ruined over time by a polluter, the exact timing does not matter as long as compensatory losses are otherwise reasonably computed. The legislatures responsible for drafting environmental laws, however, did not intend to hold trustees to impossible standards of proof. In most cases, the difficulties facing trustees were understood and expressly addressed by liberalizing standards of proof including, but not limited to, the use of rebuttable presumption. ${ }^{47}$

\section{Applicable Law Matters}

A number of factors influence the development of an NRDA, including not only science, but also applicable law and policy considerations. Such law and policy consideration, as well as applicable legal and regulatory norms are often more open to interpretation than science, which adds a layer of complexity and discretion to the trustee's discharge of his or her duties [8]. The interplay of norms and policies against science in the context of NRDAs can be seen in the following discussion of the difference between NRDA and an ecological risk assessment ("ERA"), which is typically a part of the site remediation process:

Both ERA and NRDA (specifically, the injury assessment component of NRDA) consider and evaluate adverse effects of hazardous chemical exposure on ecological resources and ecosystem processes. However, the 2 assessment programs have different programmatic and scientific objectives that derive from their respective statutory and regulatory authorities and guidance. In the context of CERCLA, ERA is performed to inform response/remedial decision making. Natural resource damage assessment, on the other hand, is aimed at compensating the public for injury, destruction, or loss of natural resources. Compensation in NRDA is achieved through the restoration, rehabilitation, replacement, or acquisition of natural resources.

As a consequence of these distinct objectives, ERA seeks to answer funda-

${ }^{46}$ The trustee has to decide, for example, which ecological changes count as "damages" and "restoration."

${ }^{47}$ See, e.g., N.J. Spill Compensation \& Control Act, N.J.S.A. 58:10-23.11x ("This act, being necessary for the general health, safety, and welfare of the people of this State, shall be liberally construed to effect its purposes."). 
mentally different questions from NRDA. Ecological risk assessment is focused on aiding remedial decision-makers in evaluating whether, and what, actions should be undertaken to manage risks to the environment. An ERA is therefore sufficient when it provides adequate information to support such decisions. Natural resource damage assessment, in contrast, is focused on quantifying the compensation necessary to restore injured resources to baseline and to offset past and future injuries to natural resources. An NRDA is therefore sufficient when adequate information is provided to support determinations regarding the nature and extent of natural resource injuries and to quantify the compensation required to offset losses to natural resources and their services [3].

This passage highlights how an ERA and NRDA could reach different conclusions about the existence of an injury, even though both are using sound science. The difference between NRDA and ERAs is not the only instance in which the trustee must differentiate between law and policy and science. Often the responsible party will conflate trustee responsibilities with its own burdens of proof, it will argue that the trustee has more responsibilities than are statutorily prescribed, and often attempts to convince the judge and jury that there is no distinguishable difference between important NRDA processes, such as injury assessments and damage assessments. The following illustrate just how important applicable law is when a trustee faces these challenges.

\subsection{Release or Discharge}

Legislatures incorporated notions of strict, joint and several liability into environmental laws to lessen the difficulties of the trustee's task to satisfy its burden of proof. ${ }^{48}$ Where pollution from different RPs is commingled, the releases often produce indivisible harms. Under those circumstances, CERCLA liability is strict, joint and several and one single contributing RP may be liable for the entirety of the damages. ${ }^{49}$ At that point, it is the RP's burden, not the trustee's, to show that the harm is capable of being allocated among other RPs. If that RP can carry its burden of proving allocation and divisibility, it is only liable for its contribution. ${ }^{50}$

Most NRD laws require a "release" or "discharge" of a hazardous substance or oil into the environment for there to be any potential recovery of damages. A release is a broad legal concept that covers intentional and unintentional releases. ${ }^{51}$ A "release" is considered to be almost any exposure of a substance to the environment, whether by spilling, leaking, pumping, pouring, emitting, emptying, discharging, injecting, escaping, leaching, dumping, or disposing. The law also treats the abandonment or discarding of barrels, containers, and other closed receptacles containing hazardous substances to be a release into the environ${ }^{48} 42$ U.S.C. $\$ 9601$ (32) (adopting Clean Water Act standard in 33 U.S.C. \$1321); see also California v. Montrose Chem., 104 F.3d 1507, 1518-19 (9th Cir. 1997); New York v. Exxon, 766 F.Supp. 177, 197 (S.D.N.Y. 1991)

${ }^{49}$ E.g., United States v. Rohn \& Hass Co., 2 F.2d 1265 (3d 1993); United States v. Alcan Aluminum, 990 F.2d 711, 722 (2d Cir. 1993).

${ }^{50} 42$ U.S.C. $\$ \$ 9607,9601(22), 9601(8)$.

${ }^{51} I d . \$ 9601(22)$. 
ment. ${ }^{52}$

Proof of release is fairly straightforward. Comprehensive chemical analyses are generally not needed. ${ }^{53}$ The volume of the hazardous substances released is irrelevant in liability related to a release.$^{54}$ Complexity arises if the sources and timing of releases matter, for example, where multiple parties contribute to the same environmental injury. If joint and several liability applies, the NRDA need not quantify or distinguish between particular sources of pollution. Ordinarily, this determination of fault and allocation is part of the contribution determination process, which is not part of a NRDA.$^{55}$ Likewise, if allocation issues arise in a multi-party settlement, these issues are approached and resolved separately from the true NRDA issues. ${ }^{56}$ The rules on allocation in the CERCLA-like context are still evolving and are applied differently under certain regimes and laws. The timing of a particular release may matter for several reasons. First, if liability is limited to injuries occurring after a certain date, the trustee must determine the timing of the injuries. Second, the timing of a release impacts the determination of the pre-pollution condition of natural resources. Timing is also relevant in cases where the degree of injury over time is relevant. Once a resource is essentially destroyed, it is less important to assess the contributions of additional ecological insults. For example, if events in 1910 destroyed a marsh, additional releases may be irrelevant to the injury assessment. In other cases, the injury may only be partial, and the process of degradation over time may be more relevant. In cases involving a "continuing injury" by a responsible party, it is generally unnecessary to determine the precise timing of each step of the injury. Despite the fact that the trustee's responsibility is to determine the injury caused by the release, defendants will consistently urge that it is the trustee's responsibility to also determine contribution in the case of multiple responsible parties.

If the correct standard of law is applied, the trustee should not be held responsible for determining contribution. In In re Acushnet River \& New Bedford Harbor: Proceedings Re Alleged PCB Pollution, ${ }^{57}$ the court held that once the government plaintiffs established at trial that non-permitted releases were a "contributing factor to an injury to natural resources and that the injury is indivisible," the defendant would be jointly and severally liable for all of the resulting injury unless it could prove that the injury was divisible. To prove divisibility, a ${ }^{52} I d . \$ 9601(22)$.

${ }^{53}$ Some disagree [4]. ("What appears to be a straightforward regulatory-driven task of confirming that a release has occurred, may, in reality, involve a complex scientific effort of verification and/or reconstruction, particularly for operating and legacy sites, to fully understand the history and characteristics of the release(s)."). This position, however, confuses "release" with other legal issues as discussed below.

${ }^{54} 42$ U.S.C. $\$ 9607$ (a) (providing no minimum requirement, unlike for reporting violations under \$9603); see also Johnson v. James Langley, 226 F.3d 957, 961 (8th Cir. 2000); Stewman v. Mid-Southwood Prods., 993 F.2d 646, 649 (9th Cir. 1993). New Jersey has also rejected any de minimus defense. N.J. Dep't of Envtl. Prot. v. Dimant, 212 N.J. 153, 174 (2012) (“There is plainly no de minimis exception to the Spill Act's prohibition against the discharge of hazardous substance.").

${ }^{55}$ Responsible parties may sue each other for contribution, where all or less than all, have been held responsible for NRD. See 42 U.S.C. $\$ 9613(f) ; 33$ U.S.C. $\$ 2709$.

${ }^{56} \mathrm{NRDA}$ practice encourages settlements. However, investigations to facilitate settlement are not necessarily part of the NRDA document.

${ }^{57} 722$ F. Supp. 893 (D. Mass. 1989) (“Acushnet VIP’). 
defendant had to establish: 1) which releases were federally permitted, and 2) which portion of the natural resource damages was allocable to the permitted releases. ${ }^{58}$ The court's insistence that the defendant prove divisibility of the injury is consistent with common law and CERCLA case law involving multiple tortfeasors, which place the burden on the defendant (not the trustee) to establish divisibility of harm. As the court stated, "it is appropriate to place the burden of divisibility on defendants when the question is one of dividing harm between permitted and non-permitted releases." ${ }^{\text {59 }}$

Allocation issues also arise in the settlement context, where responsible parties often sue other responsible parties for joint and several liability under CERCLA, $\$ 107$. In a settlement context, $\$ 113(\mathrm{f})$ contribution issues will generally also be addressed. ${ }^{60}$ In general, contribution issues should not delay damage determination, especially in CERLCA and OPA cases.

However, all courts are not particularly mindful of this goal. For example, a good case can be made that OPA's primary purpose was to ensure prompt payment of damages. ${ }^{61}$ In the case of the BP oil spill in the Gulf of Mexico, ${ }^{62} \mathrm{BP}$ immediately admitted that it was a responsible party under OPA.$^{63}$ Logically, the next question for victims would be damages (perhaps using early test cases to determine appropriate ranges). ${ }^{64}$ However, over the objections of Louisiana and the United States, ${ }^{65}$ the trial court decided to try non-jury issues of contribution and admiralty liability first, delaying resolution of OPA damages for another six years. ${ }^{66}$ It may have been that the trial court simply misunderstood the impact of OPA on general maritime law [9]. In addition to inefficient case management,

${ }^{58}$ Id. at 897 . The Third Circuit has also adopted the rule that joint and several liability is imposed in CERCLA actions when joint tortfeasors cause indivisible harm which cannot be reasonably apportioned. United States v. Rohm \& Haas Co., 939 F. Supp. 1142, 1155 (D. N.J. 1996).

${ }^{59} \mathrm{Id}$. at 901.

${ }^{60}$ See Cooper Indus. Inc. v. Ariall Servs. Inc., 543 U.S. 157 (2005); Amer-Cyanamid Co. v. Capuano, 381 F.3d 6 (1st Cir. 2004) (using discretionary allocation approach); Akzo Nobel Coatings v. Aigner Corp., 197 F.3d 302 (7th Cir. 1999) (using Uniform Contribution Among Tortfeasor Acts).

${ }^{61}$ For example, OPA also requires an interim claims system to assure that claimants receive a portion of the total recovery soon after damages occur. 33 U.S.C. $\$ 2705$.

${ }^{62}$ In re: Oil Spill by the Oil Rig "Deepwater Horizon" in the Gulf of Mexico, on April 20, 2010, MDL-2179 (E.D.La.). Resolution came after the parties reached a global settlement to resolve outstanding liabilities.

${ }^{63}$ Ex-Parte Agreed Motion Re: Applicability of Limit of Liability Under Oil Pollution Act of 1990 to BP Exploration \& Production Inc. (And its Affiliates) (Dec. 23, 2010) [Rec. Doc. 922], In re: Oil Spili by the Oil Rig "Deepwater Horizon" in the Gulf of Mexico, on April 20, 2010, MDL-2179 (E.D.La.).

${ }^{64}$ See State of Louisiana's Request for Creation of a Separate Government Track (Sept. 16, 2010)[Rec. Doc. 248], In re: Oil Spill by the Oil Rig "Deepwater Horizon" in the Gulf of Mexico, on April 20, 2010, MDL-2179 (E.D.La.) (requesting a separate government track); see also Statement of Interest of the United States Related to the Initial Pretrial Conference (Sept. 13, 2010)[Rec. Docs. 222], In re: Oi Spill by the Oil Rig "Deepwater Horizon" in the Gulf of Mexico, on April 20, 2010, MDL-2179 (E.D.La.) (briefing from the United States supporting Louisiana's position).

${ }^{65}$ See State of Louisiana's Request for Creation of a Separate Government Track (Sept. 16, 2010)[Rec. Doc. 248], In re: Oil Spill by the Oil Rig "Deepwater Horizon" in the Gulf of Mexico, on April 20, 2010, MDL-2179 (E.D.La.) (requesting a separate government track); see also Statement of Interest of the United States Related to the Initial Pretrial Conference (Sept. 13, 2010)[Rec. Docs. 222], In re: Oi Spill by the Oil Rig "Deepwater Hoizon" in the Gulf of Mexico, on April 20, 2010, MDL-2179 (E.D.La.) (briefing from the United States supporting Louisiana's position).

${ }^{66}$ Case Management Order, No. 1, In re: Oil Spill by the Oil Rig "Deepwater Horizon" in the Gulf o1 Mexico, on April 20, 2010, MDL-2179 (E.D.La. Oct. 19, 2010) (Barbier, J.). 
this also raised the constitutional problem of resolving non-jury questions before jury questions are determined. ${ }^{67}$

Precise quantification of a release (for example, an oil spill) is very difficult, if not impossible, and generally unnecessary in a NRDA. Nevertheless, understanding the range of a release may in some cases assist the trustee in assessing and quantifying the relevant habitats and resources to investigate. In some situations, quantification may serve other or additional purposes, such as in the Deepwater Horizon litigation, where the number of barrels spilled was necessary to determine Clean Water Act civil penalties. ${ }^{68}$

\subsection{Injury Assessment}

Once the trustee has determined that there has been a release, he or she may then begin the injury assessment process. CERCLA defines an injury as "an observable or measurable adverse change in a natural resource or impairment of a natural resource service," ${ }^{69}$ which may occur directly or indirectly. Examples of adverse changes include changes in survival, growth, and reproduction; health, physiology, and biological condition; behavior; community composition; ecological processes and functions; physical and chemical habitat quality or structure; and public services. ${ }^{70}$

A NRDA injury assessment measures the extent and severity of an injury to natural resources, habitats, and ecosystems. A trustee has a number of tools at its disposal to make such measurements, including time-sensitive data, insights derived from scientific literature, and mathematical models that predict the fate and effects of pollutants. Ordinarily, NRDAs include detailed information about the relationship of the "stressor" (hazardous release or oil) to the natural resource (such as groundwater, soil, vegetation, wildlife, fish, or natural habitat). The trustee responsible for the NRDA compiles and analyzes collected data and statistics to determine what might be needed to remedy or restore the injured resource, which includes identifying additional work that might be necessary at the site. ${ }^{71}$

\subsection{Baseline}

It is important to note that an injury assessment under federal law is different from a damage determination. Injuries are generally quantified against the pre-incident baseline, which can be determined in a number of ways. ${ }^{72}$ DOI regulations define the baseline as "the condition or conditions that would have ex-

\footnotetext{
${ }^{67}$ Dairy Queen, Inc. v. Wood, 369 U.S. 469 (1962).

${ }^{68} 33$ U.S.C. $\$ 1321(\mathrm{~b})(7)(\mathrm{A}),(\mathrm{D})$; see also Findings of Fact and Conclusions of Law for the Phase Two Trial In re: Oil Spill by the Oil Rig "Deepwater Horizon" in the Gulf of Mexico, on April 20, 2010, MDL-2179 (E.D.La. Jan. 15, 2015) (finding that 3.19 million barrels of oil had been released from the Macondo Well).

${ }^{69} 15$ C.F.R. $\$ 990.30$.

${ }^{70} I d . \$ 990.51(\mathrm{c})$.

${ }^{71} 15$ C.F.R. $\$ 990 ; 43$ C.F.R. $\$ 11$.

${ }^{72}$ Id.

${ }^{73} 43$ C.F.R $\$ 11.14$.
} 
isted at the assessment area had the discharge of oil or release of the hazardous substance under investigation not occurred," state of the ecosystem. Though it is rarely possible to measure a baseline with complete accuracy, trustees try to determine baseline to a reasonable degree of certainty using a variety of methods. "In some situations, baseline can be determined in a relatively straightforward manner by the use of upstream reference areas (for riverine sites) or when pre-release data are available for a site" [4]. It may be hard or impossible to find a reasonable reference area in some cases. Often, "the best available evidence is imperfect as to the precise magnitude of injury at a polluted site and as to the condition of the resource immediately prior to the discharge" [1].

There is no date that the baseline commenced, the question is merely what it would have been like had there been no incident. The baseline is the control to which the trustee can compare his or her observations of the ecosystem post-incident. The relevant regulations state that trustees can rely on three distinct conceptual approaches/metrics when quantifying injuries: 1) adverse change in the resource; 2) adverse change in the resource with subsequent translation to a reduction in services; or 3) direct estimate of the reduction in services from the incident. ${ }^{74}$

As stated above, injury refers to "measurable adverse change" in the chemical or physical quality of a resource or its viability. Under federal DOI regulations, the first step in an injury assessment is categorizing the resources at issue. ${ }^{75} \mathrm{~A}$ trustee then gives each category an injury definition. ${ }^{76}$ Third, a trustee uses acceptance criteria to determine whether an injury has occurred..$^{77}$ Finally, the trustee must link the injury to the release, discharge or spill. ${ }^{78} \mathrm{~A}$ trustee can establish exposure "with either quantitative or qualitative procedures," and it is within the trustee's discretion to "determine the most appropriate procedures to evaluate exposure on an incident-specific basis." ${ }^{79}$ The trustee is encouraged to consider a wide variety of factors during the injury assessment. The weight allotted to each fact depends on specific circumstances, including:

(1) The natural resources and services of concern;

(2) The procedures available to evaluate and quantify injury, and associated time and cost requirements;

(3) The evidence indicating exposure;

(4) The pathway from the incident to the natural resource and/or service of concern;

(5) The adverse change or impairment that constitutes injury;

(6) The evidence indicating injury;

${ }^{74} I d . \$ 990.52(\mathrm{~b})$.

${ }^{75} 43$ C.F.R. $\$ 11.61$ (addressing to surface water, groundwater, air, as well as geologic and biologic resources).

${ }^{76} I d$. $\$ 11.62$.

${ }^{77}$ See, e.g., id. $\$ \$ 11.62(\mathrm{~b})(2),(\mathrm{c})(2),(\mathrm{f})(2)$. General sampling and testing requirements also exist. Id. $\$ 11.64$.

${ }^{78}$ Id. $\$ 11.63$.

${ }^{79}$ Natural Resource Damage Assessments, 61 Fed. Reg. 440, 450-451 (Jan. 5, 1996). 
(7) The mechanism by which injury occurred;

(8) The potential degree, and spatial and temporal extent of the injury;

(9) The potential natural recovery period; and,

(10) The kinds of primary and/or compensatory restoration actions that are feasible. ${ }^{80}$

The OPA regulations instruct trustees on how to weigh these factors when determining which injuries to select for assessment.

As a part of the injury quantification process, trustees generally estimate, "quantitatively or qualitatively," the time it will take for an ecosystem to recover on its own, in the absence of active restorative measures. ${ }^{81}$ Generally, this involves a determination as to what counts as recovering. Relevant regulations do not specify which methods trustees must use to estimate natural recovery. Instead, the regulations set forth a list of factors that trustees may consider in their analysis. $^{82}$

In the course of NRD litigation, defendants may attempt to artificially limit injury assessment based on disputed legal theories. Defendants often conflate the injury assessment with the damages assessed against them. In an effort to minimize the damages for which they are responsible, defendants will read the regulations in such a way that renders injury assessments and damage assessments one in the same. For this reason, they will limit experts to specific timeframes and changing baselines. When challenging a trustee's ultimate damage assessment, defendants will challenge the injury assessment by offering up experts presenting evidence based on the skewed definitions of baseline, injury, and damage.

Polluters have attempted to advocate, for example, for the now discredited notion of a "changing baseline." According to this theory, certain polluting activity over time, including the polluter's own releases, change the baseline habitats. Therefore, they argue, polluters should not be obligated to restore the damaged habitat to pre-pollution conditions, but rather, an altered landscape. ExxonMobil advanced this position in New Jersey Department of Environmental Protection v. Exxon Mobil Corp. ${ }^{83}$ where the company argued that intertidal wetlands that had been "filled" in with decades of industrial pollution ceased being wetlands and became "disturbed uplands" instead. Therefore, ExxonMobil argued, both baseline and the restoration endpoint was as a "disturbed upland," rather than a functioning wetland habitat. On this logic, restoration becomes fairly meaningless.

A related tactic that polluters use to attempt to reduce their liability is to seek credit for other anthropogenic stressors. This gambit rarely succeeds because damages to natural resource are often the result of several environmental stressors; thus, joint and several liability applies. Polluters' invocations of notions like "urban background" also generally fail because the notion often includes the re-

${ }^{80} 15$ C.F.R. $\$ 990.51(\mathrm{f})$.

${ }^{81}$ Id. $\$ 990.52(\mathrm{c})$.

${ }^{82} \mathrm{Id}$.

${ }^{83} 393$ N.J. Super. 388 (App. Div. 2007). 
sponsible party's own toxic releases in the suggested background levels. Therefore, the resulting "baseline" is not the pre-pollution condition of the resources. More troubling, you cannot use an area a responsible party has polluted as a reference area to compare to another parcel polluted by the same responsible party. Finally, polluters have argued that pre-pollution conditions are irrelevant to the determination of a baseline. They insist that trustees determine baseline by simply modeling forward the pre-pollution site conditions without accounting for the release. This approach makes little sense and overly complicates the analysis. For example, in a recent NRD case, defendant's primary damages expert admitted that if not restricted by defense counsel's instructions to limit his evaluations of releases from the date the relevant statute was passed forward, as a scientist, he would have expanded the scope of his assessment to include the entire scope of the harm:

Q If you were doing a natural resource damage assessment and there were no lawyer instructions limiting you to 1977, would you agree that the generally-accepted practice would have been to try to go back in time to the beginning of the releases of contaminants at Bayway and Bayonne and understand what, if any, natural resources were injured or destroyed in conjunction with looking at physical modifications that may have also happened over time?

A I would agree that if there were no overriding legal or regulatory issues associated with assessment framework, that such an assessment of both the timing, the magnitude of releases and the degree of physical modification would be evaluated. ${ }^{84}$

That same expert later admitted that ignoring available historical information is actually unprecedented in NRDA:

Q Here, in this case, it's unprecedented to investigate possible injuries to natural resources without looking at historic discharges, it's unprecedented in your experience, correct?

A Let me explain that. I said that I'm unaware of any information that relates -- that would do the kind of historical evaluation that you're talking about of the relationship between any discharges and injury and relative to changes in the refinery. I'm unaware of that kind of information. I can't say that no one has ever attempted to do that in this matter, but I'm just unaware of any information that would allow that kind of determination.

Q If, in fact, that kind of information was not developed by Exxon, would you then agree that the work, the HEA ${ }^{85}$ that you're standing behind in this court is unprecedented?

A I have been involved in HEAs where there's not that kind of detailed historical information just because of a lack of information associated with the ${ }^{84}$ N.J. Dep't of Envtl. Prot. v. ExxonMobil Corp., Nos. UNN-L-3026-04, UNN-L-4415-04 (N.J. Super. Ct. Law Division), Trial Tr. (July 10, 2014) 29:11-24 (Ginn Cross).

${ }^{85} \mathrm{~A}$ "HEA," or habitat equivalency analysis, is a method developed for estimating how much restoration is needed to compensate for the loss of natural resources and their services from the time they are injured until they are returned to the condition they would have been in had the injury not occurred. See generally Brian Roach \& William Wade, Policy Evaluation of Natural Resource Injuries Using Habitat Equivalency Analysis, Ecological Econ. 421 (2006). 
kinds of things we're talking about here and, therefore, the HEA and the injury assessment was started at a later time, so I can't say that it's unprecedented.

Q Is it unprecedented to do a HEA without looking at historic discharges of hazardous materials and their potential or actual impact on natural resources, yes or no?

A Well, all HEAs that I've been involved in involve some historic evaluation of natural resources.

Q So that the work in this case, the HEA in this case for Exxon is unprecedented as you used that term yesterday, correct? Unprecedented.

A I've been involved in other HEAs where there has been a certain start date in time for the HEA application that did not involve, and typically because of just lack of information, a detailed evaluation of the kinds of information you're talking about before the start of the HEA.

Q I'm saying any information, not detailed information, any information, you haven't been involved in a HEA where there's absolutely no information, no investigation of any historic discharge, correct? Yes or no.

A I guess I would say yes. ${ }^{86}$

Given that the regulations direct trustees to look to the baseline of the ecosystem, it naturally follows that ignoring historical data is unprecedented. The expert had even stated that "baseline factors are very different from effects of hazardous substances," essentially acknowledging that there is a difference between injury assessment and damage assessment. ${ }^{87}$ In this same case, another RP expert asked the court to ignore the $100 \%$ service loss occasioned by massive contamination in favor of another, albeit, narrow view of just the top two feet of contamination. ${ }^{88}$ These instructions confuse the difference between an injury assessment and a damage assessment. The damages cannot be quantified until the injury is determined. In fact, DOI's Type B Procedures require that after determining the injury, the trustee develop a restoration and compensation plan that lists "(i) the restoration or rehabilitation of the injured natural resources to a condition where they can provide the level of services available at baseline, or (ii) the replacement and/or acquisition of equivalent natural resources capable of providing such services, and, where relevant, the compensable value." ${ }^{\prime 89}$ RP's attempts to limit injury assessments to a specific date and modified baseline contravene the purpose of the environmental statutes, that is to restore lost and impaired ecosystems. While there may be some flexibility in the method used to conduct an injury assessment, contrary to the actions of the experts described in the examples above, all experts in every case must consider all relevant facts and data in the course of a NRDA, which means fully examining the ecosystem as a whole, its history included. Though the RP may have grievances with the actual monetary amount of damages, he cannot ignore the regulations that direct a

${ }^{86}$ N.J. Dep't of Envtl. Prot. v. ExxonMobil Corp., Nos. UNN-L-3026-04, UNN-L-4415-04 (N.J. Super. Ct. Law Division), Trial Tr. (July 10, 2014) 68:4-69:23 (Ginn Cross).

${ }^{87}$ Id. Trial Tr. (July 10, 2014) 94:3-6 (Ginn Cross).

${ }^{88}$ See generally id. Trial Tr. (June 11, 2014) 109-111 (Boehm Direct).

${ }^{89} 43$ C.F.R. $\$ 11.81$. 
trustee to evaluate the injury based on the baseline of the ecosystem. Proper evaluation of large ecosystems is challenging enough without willful misinterpretation of regulations.

\subsection{Response and Injury}

During an acute environmental disaster, such as an oil spill, the initial response and actions are intended to stop the immediate spread of the toxin and prevent further harm. This response generally includes collecting data such as in a Shoreline Clean up Assessment during an oil spill that moves from the offshore environment to land. This data, though usually useful during the NRDA process, is not technically part of NRDA. In general, the RP's main goal is to use data acquired and decisions made during the response to justify terminating the response action and claiming a total cessation of natural resource injury. This is generally unwarranted and unsound science, as was seen in the BP oil spill litigation.

For example, during the early stages of the BP oil spill, response actions began almost immediately in the Gulf itself [10]. As it became clear that oil would nevertheless shortly arrive at the Louisiana coast, efforts were made to photograph and otherwise document pre-spill conditions. Once the oil reached the Louisiana marshes in 2010, a Shoreline Cleanup Assessment Technique ("SCAT") process was implemented. SCAT is a component of the response to an oil spill in which team members, from both the RP and the trustees offices, collect data from the field to be used throughout the response planning. SCAT data is often used in the NRDA, however the technique is part of the response phase. The SCAT process for the Deepwater Horizon oil spill involved people physically walking or driving on beaches or boating near marshes and recording that survey information [10]. Although beach measurements were comparatively straightforward, marsh measurements were not, given the twists, and turns of marsh shoreline. Given the positive reaction of the federal personnel working on the SCAT [10], BP claims it was led to believe that the federal government would use SCAT data to prove shoreline injury [10] and, since the number was relatively conservative, BP actively sought to promote its use in lieu of a shoreline NRDA.

Unfortunately, these SCAT survey results collected during the response suffered from many shortcomings that made them inappropriate for use in the context of assessing marsh shoreline injury. For example, the SCAT survey data was recorded on an outdated 2008 marsh shoreline map that reflected only shoreline/land interface at low tide..$^{90}$ The spatial resolution of the 2008 shoreline map failed to capture many of the details of the vegetated land-water interface where the majority of marsh oiling occurred. Unlike beaches, which are fairly linear, marshes have nooks and crannies that must certainly be assessed for purposes of determining natural resource injuries. As it turned out, marsh shoreline lengths based on the 2008 shoreline map seriously underestimated the total

${ }^{90}$ NOAA, Draft Programmatic Damage Assessment and Restoration Plan, Sec. 4.2.6; p. 4-69 to 4-71 (hereinafter PDARP). 
length of the shoreline and the length of the oiling along the vegetated marsh edge. ${ }^{91}$ Aerial photographs both before and after SCAT survey also revealed many instances of marsh oiling being missed by SCAT boats and their observers, traveling approximately 50 meters offshore. ${ }^{92}$

The Louisiana trustees concluded that SCAT response data underreported oiling in Louisiana marshes. They then allocated the available shoreline oiling information from both the response and NRDA onto a 2010 higher resolution shoreline map. The results were startling. This analysis indicated that the actual length of the oiled marsh edge in Louisiana likely exceeded the oiled length based on the 2008 map's shoreline by $20 \%-40 \%$ in many areas. ${ }^{93}$

Despite this finding, the federal trustees relied on SCAT oiling data in evidence presented during the Clean Water Act penalty phase of the trial. The deposition testimony of Jacqui Michel, the NOAA SCAT Coordinator for Louisiana, who later went to the private sector, established that SCAT survey teams had identified only 1053 miles of oiled shoreline by the end of $2010 .^{94}$

$\mathrm{BP}$ argued that that the SCAT response data was the same as data appropriate for determining injury for purposes of the NRDA. Department of Justice attorneys cross-examined BP's expert Elliot Taylor on this point. Reminiscent of the expert testimony in the previously discussed ExxonMobil case, Dr. Taylor attempted to limit his analysis to what the BP attorneys said was appropriate for determining damages, namely the SCAT data collected for initial response. Nevertheless, he ultimately conceded that other NRD assessment teams had taken chemical samples, found locations of oiling that the SCAT team had not, and that in general, NRDAs should consider all available information. When asked about the depth of analysis that goes into a SCAT, Dr. Taylor noted that SCAT does not typically take samples of the oil or environment and as such did not take into account the chemical assessments done by the NRD teams. Despite this, he maintained that his opinion was that the SCAT data was accurate and

\footnotetext{
${ }^{91} I d$.

${ }^{92} I d$.

${ }^{93} \mathrm{An}$ accurate measure of oiled shoreline also impacts the allocation of some of the settlement funds distributed to the States under the Resources and Ecosystems Sustainability, Tourist Opportunities, and Revived Economies of the Gulf Coast States Act of 2012 ("Restore Act"). Pub. L. No. 112-141, $\$ 1601,126$ Stat. 404, 588 (2012). Specifically, 30\% of the funds available through the Restore Act are to be allocated according to a formula that incorporates a number of miles of oiled shoreline in each affected state. Despite the fact that allocation of response and assessment oiling data onto the higher resolution 2010 shoreline more accurately reflects the number of miles of oiled shoreline, the Gulf Coast Restoration Council is choosing to use the SCAT oiling data obtained during the response action to determine the number of miles of oiled shoreline in each state.

${ }^{94}$ J. Michel Dep. 78:2-7 (Aug. 1, 2014), In re: Oil Spill by the Oil Rig "Deepwater Horizon" in the Gult of Mexico, on April 20, 2010, MDL-2179 (E.D.La.). The federal trustees also relied heavily on the SCAT data and the reports prepared by Jacqui Michel in sections of the Programmatic Damage Assessment and Restoration Plan (PDARP) describing the extent of oil exposure as a result of the Deepwater Horizon explosion. Using SCAT data supplemented by data compiled during Rapid Assessment surveys, the PDARP indicates that oil was observed on more than 1,300 miles of shoreline from Texas to Florida. PDARP Sec. 4.2.6; p. 4-69. The federal trustees' preference for the use of SCAT data despite evidence that it was an inaccurate measure of the total extent of oiling can be attributed to the fact that BP had already agreed to the SCAT survey analysis and was unlikely to challenge it. However, it is not the same as a bona fide NRDA.
} 
the best picture of the sustained oiling. ${ }^{95}$

BP laid a foundation for the SCAT argument in its deposition of NOAA's Dr. Jacqui Michel. When asked if the SCAT data was the "most reliable source of information about the extent of the oiling," Dr. Michel responded that the SCAT program collected information on the shorelines in a way that supports the traditional operations of shoreline surveys, which arguably could mean for shoreline surveys for the purpose of response, not NRDA. The attorney for BP attempted to emphasize the SCAT data as being the most reliable, and when Dr. Michel balked at the word reliable, she was asked if it was the most important data collected, to which Dr. Michel agreed. However, it is important to note that Dr. Michel also tried to make it clear that SCAT data are "the best source we have for oiling conditions, but they're not ... synoptic;" meaning that SCAT data are not a complete picture. ${ }^{96}$ It is also important to note that not once in BPs line of questioning did the attorney mention NRDA and the difference between response and assessment. The purpose of SCAT data is clear: to assist with the fast-paced decision-making needed during response efforts. It is not intended to be the sole information relied on in conducting a careful and complete injury assessment in order to determine the full extent of damages to natural resources impacted by a spill. There are numerous response actions after an environmental disaster, many of them take place simultaneously and may inform the other, but it is important to maintain the distinction between the initial response and the actual NRDA. It is only in this way that the trustee can fulfill the statutory objective of complete restoration.

\section{Conclusion}

The NRDAs performed by trustees contemplate many intricate decisions that consider science, law, and policy. Trustees are equipped with the necessary authority to assess the best methods to respond to a natural disaster and in turn develop the best fact record that will result in the ideal restoration plan to make the public trust and the public at large whole once more. By following this process, trustees are better equipped to properly calculate damages, pick a restoration plan, and prepare for trial.

\section{References}

[1] Kanner, A. (2015) Natural Resource Restorations. 28 Tulane Environmental Law Journal, 355, 376-391.

[2] Kanner, A. (2005) The Public Trust Doctrine, Parens Patriae, and the Attorney General as the Guardian of the State's Natural Resources. 16 Duke Environmental Law \& Policy Forum, 57, 89-90.

[3] Gala, W., et al. (2009) Ecological Risk Assessment and Natural Resource Damage Assessment: Synthesis of Assessment Procedures. Integrated Environmental As

${ }^{9}$ In re: Oil Spill by the Oil Rig "Deepwater Horizon" in the Gulf of Mexico, on April 20, 2010, MDL-2179 (E.D.La.), Tr. Tran. (Jan. 27, 2015) 1815:17-1818:25.

${ }^{96} J$. Michel Dep. 78:18-80:3, 81:23-82:1; 111:4-9; 150:21-151:1; 152:17-153:9; 156:5-20; 157:18-158:7 08/01/14, In re: Oil Spill by the Oil Rig "Deepwater Horizon" in the Gulf of Mexico, on April 20, 2010, MDL-2179 (E.D.La.) 111:4-9. 
sessment \& Mgmt, 5, 515-522. https://doi.org/10.1897/IEAM_2009-011.1

[4] d. Boehm, P. and Ginn, T.H. (2013) The Science of Natural Resource Damage Assessment. Environmental Claims Journal, 25, 185-225.

https://doi.org/10.1080/10406026.2013.785910

[5] Davis, M.A and Slobodkin, L.B. (2004) The Science and Values of Restoration Ecology. Restoration Ecology, 12, 1-3. https://doi.org/10.1111/j.1061-2971.2004.0351.x

[6] Davis, M.A. and Slobodkin, L.B. (2004) Letter. Frontiers in Ecology \& the Environment, 2, 44-45.

[7] Lackey, R.T. (2004) Societal Values and the Proper Role of Restoration Ecologists. Frontiers in Ecology \& the Environment, 2, 45-46.

[8] Lund. N.J. and Pace, N.L. (2011) Deepwater Horizon Natural Resource Damages Assessment: Where Does the Money Go? 16 Ocean \& Coastal Law Journal, 327, 351-353.

[9] Costonis, J. (2012) And Not a Drop to Drink: Admiralty Law and the BP Well Blowout, 73 Louisiana Law Review 1.

[10] Michel, J., et al. (2013) Extent and Degree of Shoreline Oiling: Deepwater Horizon Oil Spill, Gulf of Mexico, USA.

http://journals.plos.org/plosone/article?id=10.1371/journal.pone.0065087

Submit or recommend next manuscript to SCIRP and we will provide best service for you:

Accepting pre-submission inquiries through Email, Facebook, LinkedIn, Twitter, etc. A wide selection of journals (inclusive of 9 subjects, more than 200 journals)

Providing 24-hour high-quality service

User-friendly online submission system

Fair and swift peer-review system

Efficient typesetting and proofreading procedure

Display of the result of downloads and visits, as well as the number of cited articles

Maximum dissemination of your research work

Submit your manuscript at: http://papersubmission.scirp.org/

Or contact jep@scirp.org 